Check for updates

Cite this: RSC Adv., 2017, 7, 22301

Received 27th March 2017 Accepted 5th April 2017

DOI: 10.1039/c7ra03557h

rsc.li/rsc-advances

\section{Tuning of luminescence properties by controlling an aid-sintering additive and composition in $\mathrm{Na}(\mathrm{Ba} /$ $\mathrm{Sr} / \mathrm{Ca}$ ) $\mathrm{PO}_{4}: \mathrm{Eu}^{2+}$ for white LEDs}

\begin{abstract}
Qiongyu Bai, Panlai Li, (D) * Zhijun Wang, (D) * Shuchao Xu, Ting Li and Zhiping Yang
A series of $\mathrm{Na}(\mathrm{Ba} / \mathrm{Sr} / \mathrm{Ca}) \mathrm{PO}_{4}: \mathrm{Eu}^{2+}$ phosphors were prepared via a high-temperature solid-state reaction method. When the phase of $\mathrm{NaCaPO}_{4}: \mathrm{Eu}^{2+}$ was pure, the luminescence of $\mathrm{Eu}^{2+}$ was enhanced by doping the sintering-aid additive $\mathrm{NaCl}(t)$, and it showed a maxima at $t=0.03$. For $\mathrm{NaCaPO}_{4}: \mathrm{Eu}^{2+}$ with $0.03 \mathrm{NaCl}$, the XRD patterns, and emission and decay spectra demonstrated that $\mathrm{Eu}^{2+}$ ions occupied two different Ca sites with different coordination (i.e., eight and seven coordination). Therefore, two green emission bands at 510 and $542 \mathrm{~nm}$ were observed, and the emission band ranging from 480 to $510 \mathrm{~nm}$ had a weaker intensity. To obtain a cyan-broad emission, $\mathrm{Ba}^{2+}$ or $\mathrm{Sr}^{2+}$ were introduced into $\mathrm{NaCaPO}_{4}: 0.01 \mathrm{Eu}^{2+}$. The substitution of small $\mathrm{Ca}^{2+}$ ions by large $\mathrm{Ba}^{2+}$ or $\mathrm{Sr}^{2+}$ ions induced a decreased crystal field splitting of $\mathrm{Eu}^{2+}$ ions, which resulted in various full width at half maximum and a blue shift. The colors varied from green $(0.1996,0.4380)$ to blue $(0.1578,0.0978)$ under the same excitation. Overall, the phosphor has promising applications for use in white LEDs.
\end{abstract}

\section{Introduction}

Nowadays, white light-emitting diodes (LED) have attracted significant attention as next generation lighting devices due to their advantages of energy saving and long lifetime. ${ }^{1-7}$ To date, most commercial white LEDs have been fabricated via a combination of blue LED chips and yellow emitting $\mathrm{Y}_{3} \mathrm{Al}_{5} \mathrm{O}_{12}: \mathrm{Ce}^{3+}$ phosphors. However, these white LEDs exhibit a low color rendering index $(<75)$ and a high correlated color temperature $(\sim 7750 \mathrm{~K})$ due to the lack of a red component..$^{8-12}$ Today, the most effective method to obtain white light is to combine an ultraviolet (UV) LED chip with tricolor phosphors. ${ }^{13-16}$ However, it usually shows lower luminescence efficiency due to strong reabsorption. Moreover, it shows lower color vividness because the cyan component in the range of 480-520 $\mathrm{nm}$ is weaker. ${ }^{17}$ Therefore, it is necessary to develop a cyan phosphor with a broad emission band that has strong absorption in the near-UV but at the same time has no absorption in the visible region. ${ }^{18}$

Phosphate hosts with the chemical formula $\mathrm{ABPO}_{4}$ (where A and $\mathrm{B}$ are the alkali and alkaline earth cations, respectively) are good candidates as hosts due to their several advantages such as they require low synthesis temperature and have high chemical and physical stability; moreover, they exhibit excellent luminescence properties when $\mathrm{Eu}^{2+}$ is doped as an activator, such as $\mathrm{LiSrPO}_{4}$ and $\mathrm{KSrPO}_{4} \cdot{ }^{19-25}$ In our previous study, a green-emitting

Hebei Key Lab of Optic-electronic Information and Materials, College of Physics Science \& Technology, Hebei University, Baoding 071002, China. E-mail: li_panlai@ 126.com;wangzj1998@126.com
$\mathrm{NaCaPO}_{4}: \mathrm{Eu}^{2+}$ phosphor was synthesized, which can be used in a white LED. ${ }^{26}$ After this, green emission was enhanced in $\mathrm{NaCaPO}_{4}: \mathrm{Eu}^{2+}, \mathrm{Tb}^{3+}$ via energy transfer, according to Wang et $a .^{27}$ In our study, to avoid a decreased luminescence efficiency due to energy transfer and save energy, the green emission of $\mathrm{Eu}^{2+}$ ions was enhanced by doping $\mathrm{NaCl}$ as an aidsintering additive in $\mathrm{NaCaPO}_{4}$. Hence, a series of $\mathrm{NaCaPO}_{4}$ :$\mathrm{Eu}^{2+}$ phosphors was synthesized by a high temperature solidstate method. They showed a green emission band at $515 \mathrm{~nm}$; however, the emission band ranging from 480 to $510 \mathrm{~nm}$ was weaker. Therefore, to adjust the emission band and enhance the emission band in the range of $480-510 \mathrm{~nm}, \mathrm{Ba}^{2+}$ or $\mathrm{Sr}^{2+}$ ions with larger radii were introduced in $\mathrm{NaCaPO}_{4}: \mathrm{Eu}^{2+}$ with $0.03 \mathrm{NaCl}$. The emission band showed an obvious blue shift, and the color ranged from green to blue with the increasing concentrations of $\mathrm{Ba}^{2+}$ or $\mathrm{Sr}^{2+}$ ions; thus, these phosphors can be used in white LEDs.

\section{Experimental}

\subsection{Sample preparation}

A series of phosphors with the composition $\mathrm{NaCaPO}_{4}: x \mathrm{Eu}^{2+}$ with $t \mathrm{NaCl}(t=0.01-0.05 \mathrm{~mol}$ and $x=0.001-0.10 \mathrm{~mol})$, $\mathrm{Na}\left(\mathrm{Ba}_{a} \mathrm{Ca}_{b}\right) \mathrm{PO}_{4}: 0.01 \mathrm{Eu}^{2+}$ with $0.03 \mathrm{NaCl}$ and $\mathrm{Na}\left(\mathrm{Sr}_{c} \mathrm{Ca}_{d}\right)$ $\mathrm{PO}_{4}: 0.01 \mathrm{Eu}^{2+}$ with $0.03 \mathrm{NaCl}$ were synthesized by a high temperature solid state method using reagent grade $\mathrm{CaCO}_{3}$, $\mathrm{BaCO}_{3}, \mathrm{SrCO}_{3}, \mathrm{NaCl}, \mathrm{Na}_{2} \mathrm{CO}_{3}, \mathrm{NH}_{4} \mathrm{H}_{2} \mathrm{PO}_{4}$, and $\mathrm{Eu}_{2} \mathrm{O}_{3}(99.99 \%)$ as raw materials. Starting materials were weighed according to stoichiometric proportion, thoroughly mixed, and ground using an agate mortar and pestle for more than 30 min until they were 
uniformly distributed. The obtained mixtures were heated at $1200{ }^{\circ} \mathrm{C}$ for $2 \mathrm{~h}$ in the reduction environment $\left(95 \% \mathrm{H}^{2}+5 \% \mathrm{~N}^{2}\right)$ and then naturally cooled down to room temperature to obtain the final phosphors.

\subsection{Characterization}

A Bruker D8 X-ray diffractometer was utilized to examine the Xray powder diffraction (XRD) with $\mathrm{Ni}$-filtered $\mathrm{Cu} \mathrm{K} \alpha$ radiation $(\lambda$ $=0.15418 \mathrm{~nm}$ ), operating at $40 \mathrm{~mA}$ and $40 \mathrm{kV}$. The step length and diffraction range were $0.05^{\circ}$ and $10-80^{\circ}$, respectively. To analyze the chemical composition of the phosphors, scanning electron microscopy (SEM) images and electron-dispersive X-ray (EDX) data were obtained by a Nova NanoSEM 650 with the accelerating voltage of $10 \mathrm{kV}$. Room temperature photoluminescence spectra of the samples were obtained via a Hitachi F-4600 fluorescence spectrophotometer using a $450 \mathrm{~W}$ Xe lamp as the excitation source, with the scanning wavelength ranging from 200 to $700 \mathrm{~nm}$, scanning at $240 \mathrm{~nm} \mathrm{~min}{ }^{-1}$. The temperature-dependent luminescent properties were obtained using a computer-controlled electric furnace and a self-made heating attachment. Luminescence decay curves and quantum efficiencies of the samples were obtained using a Horiba FL4600 fluorescence spectrophotometer. Herein, to obtain the luminescence decay curves, a nano-LED (370 $\mathrm{nm})$ was used as the excitation source. The Commission International de I'Eclairage (CIE) coordinates for all samples were measured by a PMS-80 UV-VIS NEAR IR spectra analysis system.

\section{Results and discussion}

\section{1 $\mathrm{NaCaPO}_{4}: 0.01 \mathrm{Eu}^{2+}$ with $t \mathrm{NaCl}$}

$\mathrm{NaCaPO}_{4}: \mathrm{Eu}^{2+}$ showed a broad emission band at $505 \mathrm{~nm}$, according to our previous study. ${ }^{26}$ However, it showed weaker luminescence intensity. Hence, we introduced $\mathrm{NaCl}$ as an aidsintering additive to enhance the emission intensity. To verify the influence of $\mathrm{NaCl}$ on the emission intensity, the concentration of $\mathrm{Eu}^{2+}$ was randomly fixed at $0.01 \mathrm{~mol}$. Fig. 1 shows the XRD patterns of $\mathrm{NaCaPO}_{4}: 0.01 \mathrm{Eu}^{2+}$ and $\mathrm{NaCaPO}_{4}: 0.01 \mathrm{Eu}^{2+}$ with $t \mathrm{NaCl}(t=0.01,0.02,0.03,0.04$, and 0.05$)$. It can be seen that the XRD patterns of $\mathrm{NaCaPO}_{4}: 0.01 \mathrm{Eu}^{2+}$ with $t \mathrm{NaCl}$ are indexed to $\mathrm{NaCaPO}_{4}$ (JCPDS no. 29-1193) and no impurity phase was detected, indicating that $\mathrm{NaCl}$ has no influence on the phase of the phosphor. To further investigate the influence of $\mathrm{NaCl}$ on the phase of the phosphor, the crystal structure of $\mathrm{NaCaPO}_{4}: 0.01 \mathrm{Eu}^{2+}$ with $0.03 \mathrm{NaCl}$ sample was refined using the General Structure Analysis System (GSAS) program. ${ }^{28}$ Fig. 2 shows the XRD pattern for Rietveld structure analysis of $\mathrm{NaCaPO}_{4}: 0.01 \mathrm{Eu}^{2+}$ with $0.03 \mathrm{NaCl}$ based on the $\mathrm{NaCaPO}_{4}$ phase model, and no impurity phase was detected. The final profile $R$ factors, $R_{\mathrm{wp}}, R_{\mathrm{p}}$, and $\chi^{2}$ obtained were $8.62 \%, 6.19 \%$ and 1.539 , respectively, which suggested that the pure $\mathrm{NaCaPO}_{4}: 0.01 \mathrm{Eu}^{2+}$ with $0.03 \mathrm{NaCl}$ was successfully synthesized. $\mathrm{NaCaPO}_{4}$ was indexed to an orthorhombic crystal system and space group Pnam ( $a=0.6797 \mathrm{~nm}, b=0.9165 \mathrm{~nm}, c=0.5406 \mathrm{~nm}$, and $V=$ $\left.0.3368 \mathrm{~nm}^{3}\right)$. The cell parameters and volume of $\mathrm{NaCaPO}_{4}: 0.01 \mathrm{Eu}^{2+}$ with $0.03 \mathrm{NaCl}$ were $a=0.680 \mathrm{~nm}, b=$

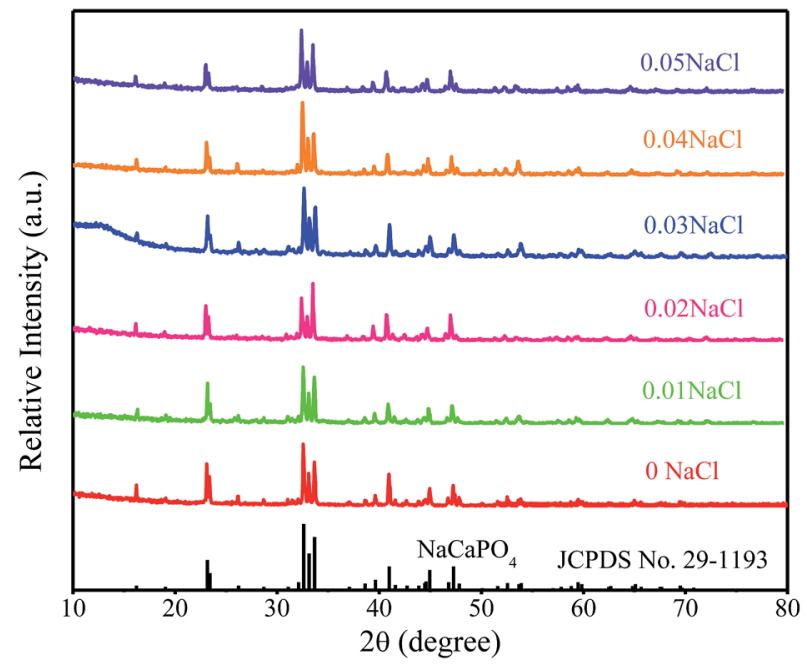

Fig. 1 XRD patterns of $\mathrm{NaCaPO}_{4}: 0.01 \mathrm{Eu}^{2+}$ and $\mathrm{NaCaPO}_{4}: 0.01 \mathrm{Eu}^{2+}$ with $t \mathrm{NaCl}(t=0.01,0.02,0.03,0.04$, and 0.05$)$. The standard data for $\mathrm{NaCaPO}_{4}$ (JCPDS no. 29-1193) are shown as a reference.

$0.916 \mathrm{~nm}, c=0.542 \mathrm{~nm}$, and $V=0.3376 \mathrm{~nm}^{3}$, which are larger than those of $\mathrm{NaCaPO}_{4}$, indicating that $\mathrm{Eu}^{2+}$ was doped into the host. The crystal structure of $\mathrm{NaCaPO}_{4}$ viewed down the $b$-axis and the coordination polyhedron was composed of a $\mathrm{Na} / \mathrm{Ca} / \mathrm{P}$ atomic site, as shown in Fig. 2. A total of three independent $\mathrm{Na}$ and $\mathrm{Ca}$ cation polyhedral sites were available with the coordination number ranging from 6 to 8 in the unit cell of $\mathrm{NaCaPO}_{4}$. Fig. 2 shows the presence of three different crystallographic $\mathrm{Na}$ environments: seven-coordinated $\mathrm{Na}(1)$ atom with
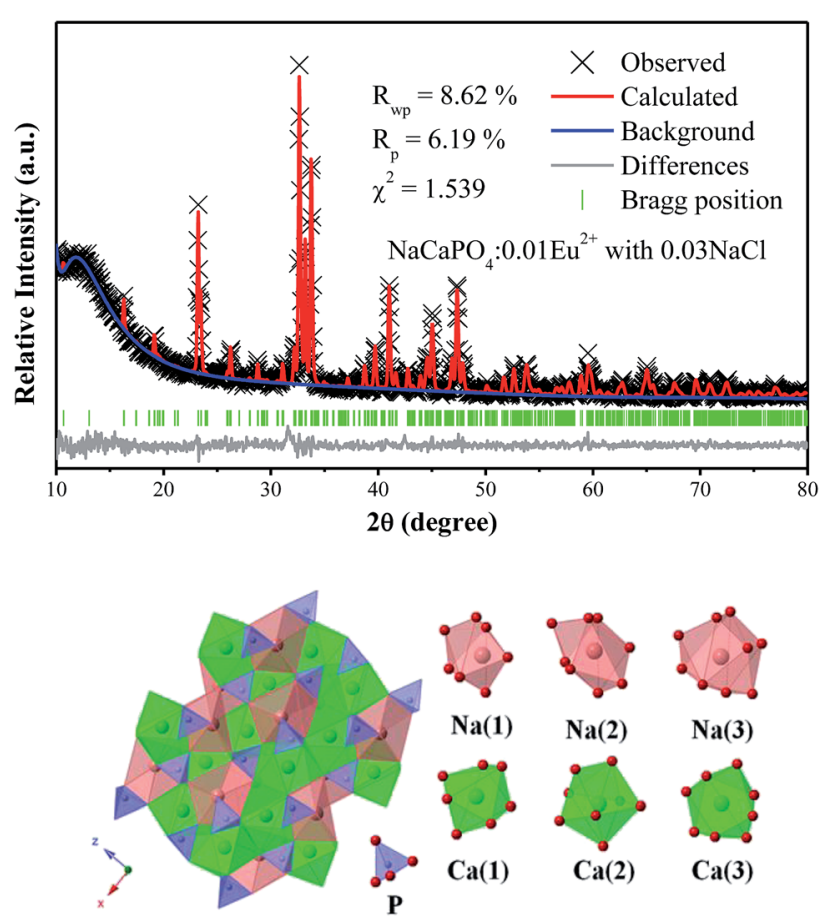

Fig. 2 XRD Rietveld refinement result of $\mathrm{NaCaPO}_{4}: 0.01 \mathrm{Eu}^{2+}$ with $0.03 \mathrm{NaCl}$, and the crystal structure of $\mathrm{NaCaPO}_{4}$. 


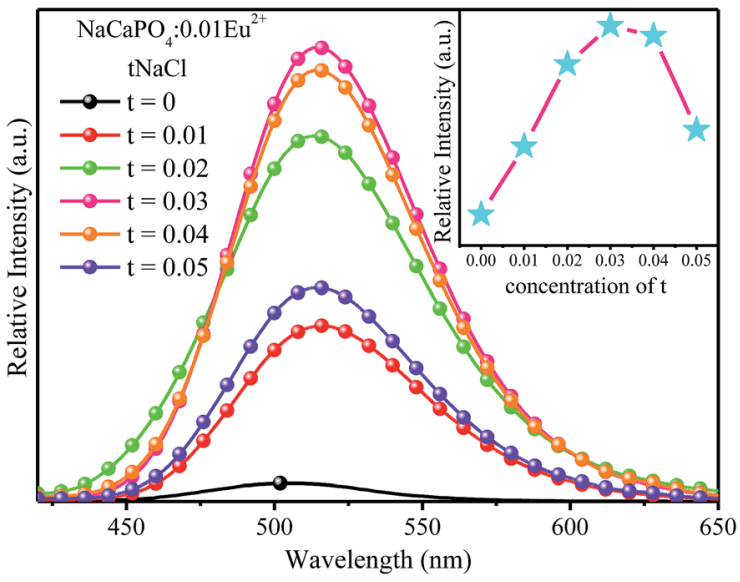

Fig. 3 Emission spectra of $\mathrm{NaCaPO}_{4}: 0.01 \mathrm{Eu}^{2+}$ and $\mathrm{NaCaPO}_{4}: 0.01-$ $\mathrm{Eu}^{2+}$ with $\mathrm{tNaCl}(t=0.01,0.02,0.03,0.04$, and 0.05$)$ excited at $365 \mathrm{~nm}$. The inset shows the emission intensity at $515 \mathrm{~nm}$ depending on $t$ concentration.

an average $\mathrm{Na}(1)-\mathrm{O}$ distance of $0.260 \mathrm{~nm}, \mathrm{Na}(2)$ atom surrounded by eight $\mathrm{O}$ atoms at the average distances of $0.264 \mathrm{~nm}$, and $\mathrm{a} \mathrm{Na(3)} \mathrm{atom} \mathrm{that} \mathrm{was} \mathrm{nine-coordinated} \mathrm{by} \mathrm{nine} \mathrm{O}$ atoms at the average $\mathrm{Na}(3)-\mathrm{O}$ distance of $0.268 \mathrm{~nm}$. There were three crystallographic positions of $\mathrm{Ca}$ in the unit cell: sevencoordinated $\mathrm{Ca}^{2+}$ sites $(\mathrm{Ca}(1))$ with the average $\mathrm{Ca}-\mathrm{O}$ distance of $0.244 \mathrm{~nm}$ and two eight-coordinated $\mathrm{Ca}^{2+}$ sites $(\mathrm{Ca}(2) / \mathrm{Ca}(3))$ with the average $\mathrm{Ca}-\mathrm{O}$ distance of $0.246 \mathrm{~nm}$ and $0.249 \mathrm{~nm}$, respectively. $\mathrm{P}$ atoms with four-coordination modes could also be observed.

Fig. 3 shows the emission spectra of $\mathrm{NaCaPO}_{4}: 0.01 \mathrm{Eu}^{2+}$ and $\mathrm{NaCaPO}_{4}: 0.01 \mathrm{Eu}^{2+}$ with $t \mathrm{NaCl}(t=0.01,0.02,0.03,0.04$, and 0.05 ) excited at $365 \mathrm{~nm}$. They exhibited a green emission band ranging from 400 to $600 \mathrm{~nm}$. The intensity of $\mathrm{NaCaPO}_{4}: 0.01 \mathrm{Eu}^{2+}$ with $t \mathrm{NaCl}$ increased with the increase in $\mathrm{Eu}^{2+}$ ions, reached a maximum at $t=0.03$, and then decreased (inset of Fig. 3). Compared to $\mathrm{NaCaPO}_{4}: 0.01 \mathrm{Eu}^{2+}$, the intensity of $\mathrm{NaCaPO}_{4}: 0.01 \mathrm{Eu}^{2+}$ with $0.03 \mathrm{NaCl}$ was 10 times enhanced. Therefore, to further investigate the influence of doping concentration on luminescence and improve the luminescent properties, a series of $\mathrm{Na}(\mathrm{Ba} / \mathrm{Sr} / \mathrm{Ca}) \mathrm{PO} 4: \mathrm{Eu}^{2+}$ with $0.03 \mathrm{NaCl}$ was synthesized.

\section{2 $\mathrm{Na}(\mathrm{Ba} / \mathrm{Sr} / \mathrm{Ca}) \mathrm{PO}_{4}: \mathrm{Eu}^{2+}$ with $0.03 \mathrm{NaCl}$}

3.2.1 Phase formation and structure. The XRD patterns and the magnified patterns between $22^{\circ}$ and $24^{\circ}$ of $\mathrm{NaCaPO}_{4}$ :- $^{-}$ $x \mathrm{Eu}^{2+}$ with $0.03 \mathrm{NaCl}$ with $x=0.001,0.01,0.03$, and 0.05 are shown in Fig. $4 \mathrm{a}$ and $\mathrm{b}$, respectively. It can be seen that all the peaks could be indexed to standard JCPDS no. 29-1193, suggesting that the phosphors are high-purity. According to the effective ionic radii of cations, $\mathrm{Eu}^{2+}$ ions were proposed to occupy the $\mathrm{Ca}^{2+}$ sites in $\mathrm{NaCaPO}_{4}$. The ionic radii for the sevenand eight-coordinated $\mathrm{Ca}^{2+}$ ions were 0.106 and $0.112 \mathrm{~nm}$, respectively; thus, the $\mathrm{Ca}^{2+}$ sites in $\mathrm{NaCaPO}_{4}$ may be occupied by $\mathrm{Eu}^{2+}$ ions with similar ionic radii of 0.121 and $0.125 \mathrm{~nm}$ for the same coordination, respectively. The diffraction peaks of
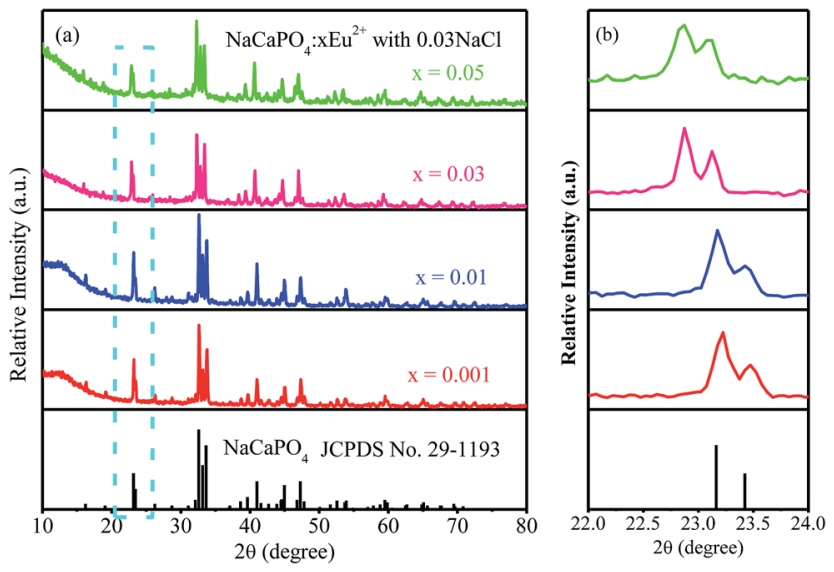

Fig. $4 \mathrm{XRD}$ patterns (a) and magnified patterns between $22^{\circ}$ and $24^{\circ}$ (b) of $\mathrm{NaCaPO}_{4}: x \mathrm{Eu}^{2+}$ with $0.03 \mathrm{NaCl}(x=0.001,0.01,0.03$, and 0.05$)$. The standard data for $\mathrm{NaCaPO}_{4}$ (JCPDS no. 29-1193) are shown as a reference.

Table 1 Cell parameters and volumes of $\mathrm{NaCaPO}_{4}: \mathrm{Eu}^{2+}$ with $0.03 \mathrm{NaCl}$

\begin{tabular}{llllll}
\hline & \multicolumn{2}{l}{ Cell parameters } & & $\frac{\text { Volumes }}{2}$ \\
\cline { 2 - 4 } Formula & $a(\mathrm{~nm})$ & $b(\mathrm{~nm})$ & $c(\mathrm{~nm})$ & $\frac{V\left(\mathrm{~nm}^{3}\right)}{2}$ \\
\hline $\mathrm{NaCaPO}_{4}: 0.001 \mathrm{Eu}^{2+}$ & 0.6798 & 0.9158 & 0.5412 & 0.3369 \\
$\mathrm{NaCaPO}_{4}: 0.01 \mathrm{Eu}^{2+}$ & 0.6800 & 0.9160 & 0.5420 & 0.3376 \\
$\mathrm{NaCaPO}_{4}: 0.03 \mathrm{Eu}^{2+}$ & 0.6810 & 0.9168 & 0.5430 & 0.3390 \\
$\mathrm{NaCaPO}_{4}: 0.05 \mathrm{Eu}^{2+}$ & 0.6815 & 0.9169 & 0.5464 & 0.3414
\end{tabular}

$\mathrm{NaCaPO}_{4}: x \mathrm{Eu}^{2+}$ with $0.03 \mathrm{NaCl}$ slightly shifted to a lower angle, and it can be seen from Table 1 that the unit cell expanded with the increasing $\mathrm{Eu}^{2+}$ concentration. Because the radius of $\mathrm{Ca}^{2+}$ is

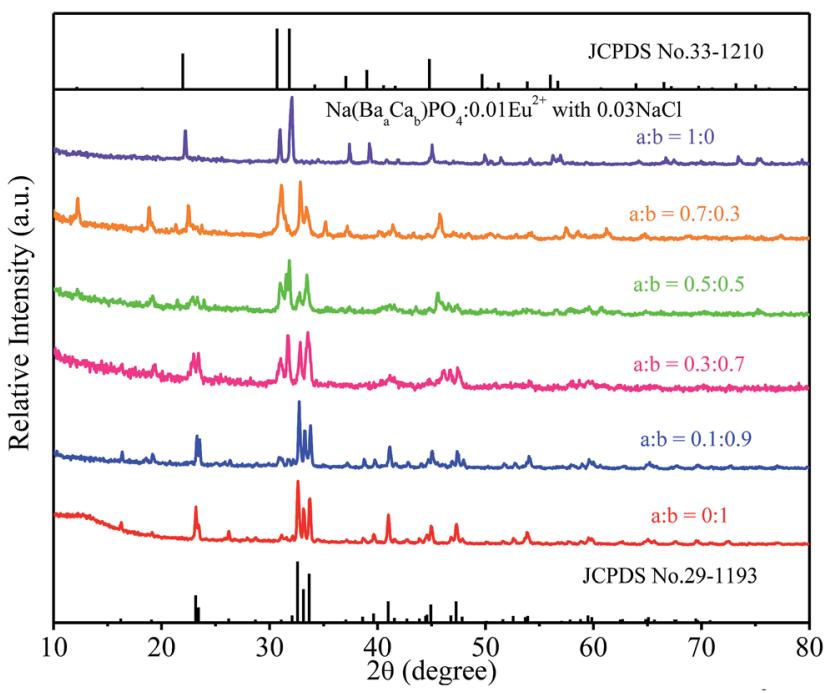

Fig. 5 XRD patterns of $\mathrm{Na}\left(\mathrm{Ba}_{a} \mathrm{Ca}_{b}\right) \mathrm{PO}_{4}: 0.01 \mathrm{Eu}^{2+}$ with $0.03 \mathrm{NaCl}$ and standard data (JCPDS no. 29-1193 and JCPDS no. 33-1210). 


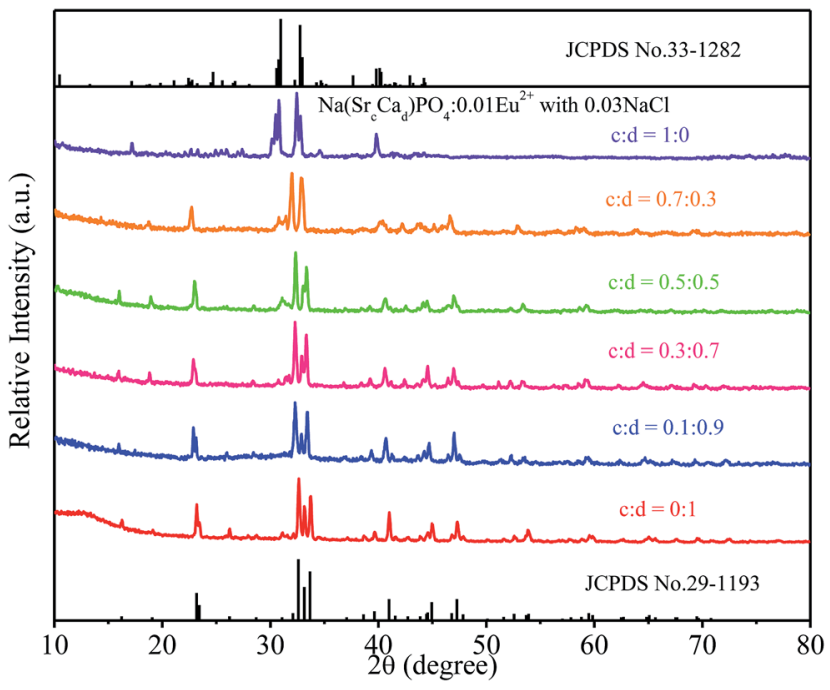

Fig. 6 XRD patterns of $\mathrm{Na}\left(\mathrm{Sr}_{C} \mathrm{Ca}_{d}\right) \mathrm{PO}_{4}: 0.01 \mathrm{Eu}^{2+}$ with $0.03 \mathrm{NaCl}$ and standard data (JCPDS no. 29-1193 and JCPDS no. 33-1282).

slightly smaller than that of $\mathrm{Eu}^{2+}, \mathrm{Eu}^{2+}$ can be easily doped into the host lattice and substituted for the site of $\mathrm{Ca}^{2+}$ ions.

XRD patterns of $\mathrm{Na}\left(\mathrm{Ba}_{a} \mathrm{Ca}_{b}\right) \mathrm{PO}_{4}: 0.01 \mathrm{Eu}^{2+}$ with $0.03 \mathrm{NaCl}(a: b$ $=0: 1,0.1: 0.9,0.3: 0.7,0.5: 0.5,0.7: 0.3$, and $1: 0$ ) phosphors are given in Fig. 5. The standard data for $\mathrm{NaCaPO}_{4}$ (JCPDS no. 29-1193) and $\mathrm{NaBaPO}_{4}$ (JCPDS no. 33-1210) are also shown as a reference in Fig. 5 . We can see that $\mathrm{Na}\left(\mathrm{Ba}_{a} \mathrm{Ca}_{b}\right) \mathrm{PO}_{4}: 0.01 \mathrm{Eu}^{2+}$ with $0.03 \mathrm{NaCl}$ can be basically indexed to the $\mathrm{NaCaPO}_{4}$ phase (JCPDS no. 29-1193) when $a \leq 0.5$. The phases of $\mathrm{Na}\left(\mathrm{Ba}_{a} \mathrm{Ca}_{b}\right)$ $\mathrm{PO}_{4}: 0.01 \mathrm{Eu}^{2+}$ with $0.03 \mathrm{NaCl}$ agreed well with the standard data for the $\mathrm{NaBaPO}_{4}$ phase (JCPDS no. 33-1210) with the increase of $a$.

To further investigate the phase formation depending on the $\mathrm{Sr} / \mathrm{Ca}$ substitution of $\mathrm{Na}\left(\mathrm{Sr}_{c} \mathrm{Ca}_{d}\right) \mathrm{PO}_{4}: 0.01 \mathrm{Eu}^{2+}$ with $0.03 \mathrm{NaCl}$ phosphors, XRD patterns for the selected samples were obtained and are shown in Fig. 6. All the diffraction peaks of the selected samples agreed well with the standard data for the $\mathrm{NaCaPO}_{4}$ phase (JCPDS no. 29-1193) and $\mathrm{NaSrPO}_{4}$ phase (JCPDS no. 33-1282), indicating that $\mathrm{Eu}^{2+}$ ions were successfully incorporated in the host without noticeably changing the crystal structure.

Fig. 7a-c shows the representative SEM images and EDX spectra of $\mathrm{NaCaPO}_{4}: 0.01 \mathrm{Eu}^{2+}$ with $0.03 \mathrm{NaCl}, \mathrm{Na}\left(\mathrm{Ba}_{a} \mathrm{Ca}_{b}\right)$ $\mathrm{PO}_{4}: 0.01 \mathrm{Eu}^{2+}$ with $0.03 \mathrm{NaCl}(a: b=0.3: 0.7)$ and $\mathrm{Na}\left(\mathrm{Sr}_{c} \mathrm{Ca}_{d}\right)$ $\mathrm{PO}_{4}: 0.01 \mathrm{Eu}^{2+}$ with $0.03 \mathrm{NaCl}(c: d=0.3: 0.7)$. It can be clearly observed that the grains of $\mathrm{NaCaPO}_{4}: 0.01 \mathrm{Eu}^{2+}$ with $0.03 \mathrm{NaCl}$ have a spherical shape, and the EDX results indicates that the phosphor has a chemical composition of $\mathrm{Na}, \mathrm{Ca}, \mathrm{P}, \mathrm{O}, \mathrm{Cl}$, and Eu. Phosphors showed an irregular shape of blocky particles when $\mathrm{Ba}^{2+}$ and $\mathrm{Sr}^{2+}$ were doped in $\mathrm{NaCaPO}_{4}: 0.01 \mathrm{Eu}^{2+}$ with $0.03 \mathrm{NaCl}$. The EDX spectra of $\mathrm{Na}\left(\mathrm{Ba}_{a} \mathrm{Ca}_{b}\right) \mathrm{PO}_{4}: 0.01 \mathrm{Eu}^{2+}$ with $0.03 \mathrm{NaCl}(a: b=0.3: 0.7)$ and $\mathrm{Na}\left(\mathrm{Sr}_{c} \mathrm{Ca}_{d}\right) \mathrm{PO}_{4}: 0.01 \mathrm{Eu}^{2+}$ with $0.03 \mathrm{NaCl}(c: d=0.3: 0.7)$ confirmed the presence of all elements in the samples. These results suggest that wellcrystallized powders were obtained.

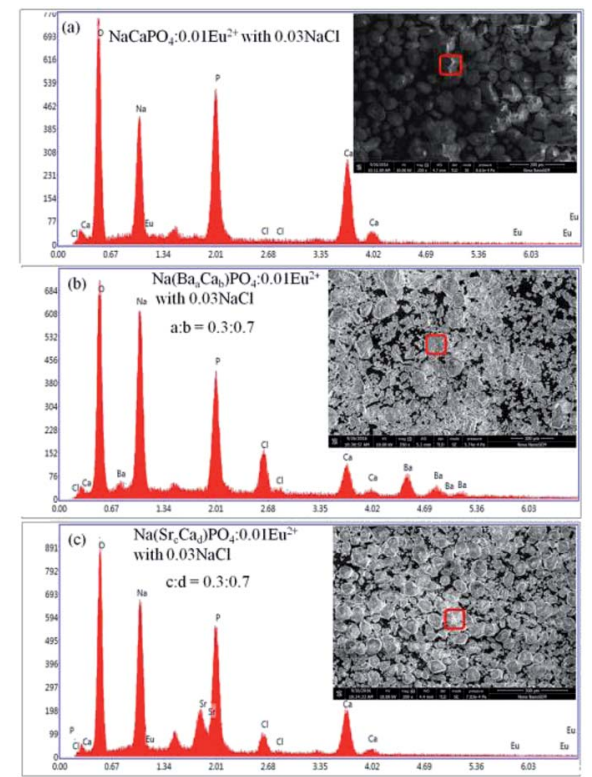

Fig. 7 SEM images and EDX spectra of $\mathrm{NaCaPO}_{4}: 0.01 \mathrm{Eu}^{2+}$ with $0.03 \mathrm{NaCl}, \mathrm{Na}\left(\mathrm{Ba}_{a} \mathrm{Ca}_{b}\right) \mathrm{PO}_{4}: 0.01 \mathrm{Eu}^{2+}$ with $0.03 \mathrm{NaCl}(a: b=0.3: 0.7)$ and $\mathrm{Na}\left(\mathrm{Sr}_{c} \mathrm{Ca}_{d}\right) \mathrm{PO}_{4}: 0.01 \mathrm{Eu}^{2+}$ with $0.03 \mathrm{NaCl}(c: d=0.3: 0.7)$.

\subsubsection{Luminescence properties}

3.2.2.1 $\mathrm{NaCaPO}_{4}: \mathrm{Eu}^{2+}$ with $0.03 \mathrm{NaCl}$. Fig. 8a-f show the emission spectra of $\mathrm{NaCaPO}_{4}: x \mathrm{Eu}^{2+}$ with $0.03 \mathrm{NaCl}(x=0.001$, $0.01,0.03,0.05,0.07$, and 0.10 ) excited at $365 \mathrm{~nm}$, respectively. We fitted the emission spectra with a Gaussian function for $\mathrm{NaCaPO}_{4}: x \mathrm{Eu}^{2+}$ with $0.03 \mathrm{NaCl}$. The orange dashed lines denote two Gaussian functions, which successfully fitted with the maxima at 510 (Eu2) and 542 (Eu1) nm. Moreover, two different emission bands were obtained due to the different crystal surroundings of $\mathrm{Eu}^{2+}$ sites. From the XRD patterns and structural analysis, it can be inferred that $\mathrm{Eu}^{2+}$ ions occupied $\mathrm{Ca}^{2+}$ sites in $\mathrm{NaCaPO}_{4}$. Hence, three distinct crystallographic sites were formed (i.e., $\mathrm{Ca}(1), \mathrm{Ca}(2)$, and $\mathrm{Ca}(3)$, in which both the crystallographic sites of $\mathrm{Ca}(2)$ and $\mathrm{Ca}(3)$ were eightcoordinated).

Therefore, the emission spectra were fitted by two Gaussian curves, and due to this, the luminescence of the luminescence centers with similar coordinate environments was indistinguishable, according to crystal field theory. ${ }^{29}$ In addition, to investigate the relationship between the coordinate environment and emission peaks, the emission position of $\mathrm{Eu}^{2+}$ can be simply estimated using the Van Uitert eqn (1): $:^{30,31}$

$$
E=Q\left[1-\left(\frac{V}{4}\right)^{\frac{1}{V}} \times 10^{\frac{n E_{\mathrm{a}} r}{80}}\right]
$$

where $E$ is the energy location of the lower d-band edge for $\mathrm{Eu}^{2+}$ $\left(\mathrm{cm}^{-1}\right), Q$ is the energy location for the lower d-band edge of the free ion $\left(Q=34000 \mathrm{~cm}^{-1}\right.$ for $\left.\mathrm{Eu}^{2+}\right), V$ is the valence of the active cation $\left(V=2\right.$ for $\left.\mathrm{Eu}^{2+}\right), n$ is the coordination number, and $r$ is the radius of the host cation $\left(\mathrm{Ca}^{2+}\right)$ replaced by the activator $\mathrm{Eu}^{2+}$ ion $(\AA)$. The value of $E_{\mathrm{a}}$ was difficult to obtain due to the complexity of the host, but it was constant in the same host. $E$ is 


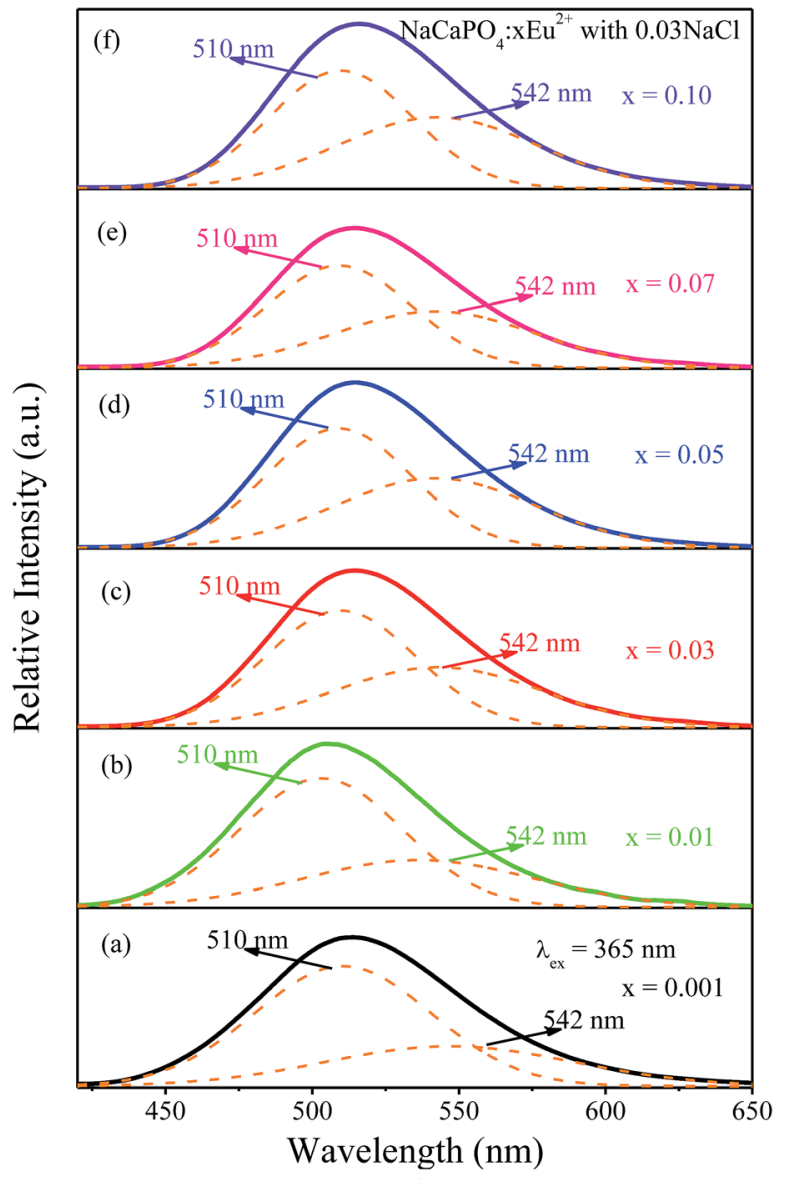

Fig. 8 Emission spectra of $\mathrm{NaCaPO}_{4}: x \mathrm{Eu}^{2+}$ with $0.03 \mathrm{NaCl}(x=0.001$, $0.01,0.03,0.05,0.07$, and 0.10$)$ and the corresponding fitted curves.

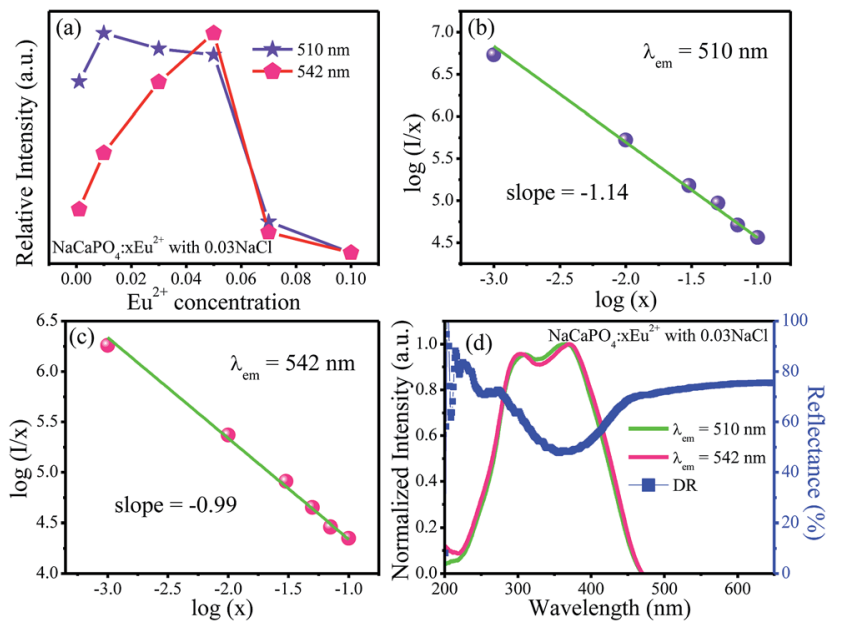

Fig. 9 (a) Variation of emission intensity for $\mathrm{NaCaPO}_{4}: \mathrm{Eu}^{2+}$ with $0.03 \mathrm{NaCl}$ as a function of doped $\mathrm{Eu}^{2+}$ concentration. (b) and (c) The relationship of $\log (/ / x)$ versus $\log (x)$. (d) $D R$, excitation spectra, and fitted curves of $\mathrm{NaCaPO}_{4}: 0.01 \mathrm{Eu}^{2+}$ with $0.03 \mathrm{NaCl}$, monitored at 510 and $542 \mathrm{~nm}$.

proportional to the $n$ and $r$ of the sample; hence, $\mathrm{Eu}^{2+}$ ions with a higher coordination number generally emit at a higher energy, corresponding to a lower wavelength. As a result, 510 (Eu2) and
$542 \mathrm{~nm}$ (Eu1) emission bands correspond to $\mathrm{Ca}(2)(\mathrm{Ca}(3))$ and $\mathrm{Ca}(1)$, respectively.

Fig. 9a shows the emission intensities of 510 (Eu2) and $542 \mathrm{~nm}$ (Eu1) as a function of $\mathrm{Eu}^{2+}$ contents; it can be observed that their emission intensities gradually increased before reaching the maximum at $x=0.01$ for $510 \mathrm{~nm}$ emission and $x=$ 0.05 for $542 \mathrm{~nm}$ emission, respectively. The emission intensities began to decrease with the increasing concentrations of $\mathrm{Eu}^{2+}$ due to the concentration quenching effect, resulting from the non-radiative energy migration among the activator $\mathrm{Eu}^{2+}$ ions.

Therefore, to further investigate the process of concentration quenching, the type of interaction among the activator $\mathrm{Eu}^{2+}$ ions was calculated by the following equation: ${ }^{32-35}$

$$
I / x=K\left[1+\beta(x)^{\theta / 3}\right]^{-1}
$$

where $I$ and $x$ represent the emission intensity and the concentration of the activator ion, respectively; $\beta$ and $K$ are the specific constants for a given host crystal and excitation condition, and $\theta$ $=3,6,8$ or 10 denotes the non-radiative energy transfer mechanism of exchange coupling, dipole-dipole, dipole-quadrupole, and quadrupole-quadrupole interactions, respectively. The fitted lines of $\log (I / x)$ versus $\log (x)$ for two emission bands centered at 510 and $542 \mathrm{~nm}$ are shown in Fig. 9b and c, respectively. The slopes of two fitted lines for 510 and $542 \mathrm{~nm}$ emission bands were -1.14 and -0.99 , respectively. Therefore, the values of $\theta$ were 3.42 and 2.97 , close to 3 , implying that the main concentration quenching mechanism of $\mathrm{Eu}^{2+}$ ions for both 510 and $542 \mathrm{~nm}$ emission bands in $\mathrm{NaCaPO}_{4}$ host were the exchange coupling interactions. Fig. 9d shows the DR and excitation spectra of $\mathrm{NaCaPO}_{4}: 0.01 \mathrm{Eu}^{2+}$ with $0.03 \mathrm{NaCl}$, monitored at 510 and $542 \mathrm{~nm}$. It can be seen that the DR spectrum matched well with the excitation spectra of $\mathrm{NaCaPO}_{4}: 0.01 \mathrm{Eu}^{2+}$ with $0.03 \mathrm{NaCl}$. $\mathrm{NaCaPO}_{4}: 0.01 \mathrm{Eu}^{2+}$ with $0.03 \mathrm{NaCl}$ exhibited a broad absorption band from 200 to $450 \mathrm{~nm}$, which was due to the transition of $\mathrm{Eu}^{2+}$ that originated from $4 \mathrm{f}^{7}$ ground state to $4 \mathrm{f}^{6} 5 \mathrm{~d}$ excitation state. For the excitation spectra monitored at 510 and $542 \mathrm{~nm}$, the spectral width at $542 \mathrm{~nm}$ was larger than that at $510 \mathrm{~nm}$ due to emission bands that originate from different $\mathrm{Eu}^{2+}$ luminescence centers. To further study the reason for different excitation spectra monitored at 510 and $542 \mathrm{~nm}$, their decay curves were measured, as shown in Fig. 10a and b, respectively. A single exponential was used to fit the decay curves, and the effective lifetimes could be defined as: $:^{36,37}$

$$
\tau=\frac{\int_{0}^{\infty} t I(t) \mathrm{d} t}{\int_{0}^{\infty} I(t) \mathrm{d} t}
$$

where $I(t)$ is the emission intensity at time $t$ and $\tau$ is the decay lifetime. The corresponding lifetimes at 510 and $542 \mathrm{~nm}$ for $\mathrm{NaCaPO}_{4}: x \mathrm{Eu}^{2+}$ with $0.03 \mathrm{NaCl}$ are shown in Fig. $10 \mathrm{a}$ and $\mathrm{b}$, respectively. For example, the lifetimes of $\mathrm{NaCaPO}_{4}: 0.01 \mathrm{Eu}^{2+}$ with $0.03 \mathrm{NaCl}$ for 510 and $542 \mathrm{~nm}$ emission bands were calculated to be $339.01 \mathrm{~ns}$ and $320.22 \mathrm{~ns}$, respectively, which implies that two emission bands were attributed to two different $\mathrm{Eu}^{2+}$ ion luminescence centers. 

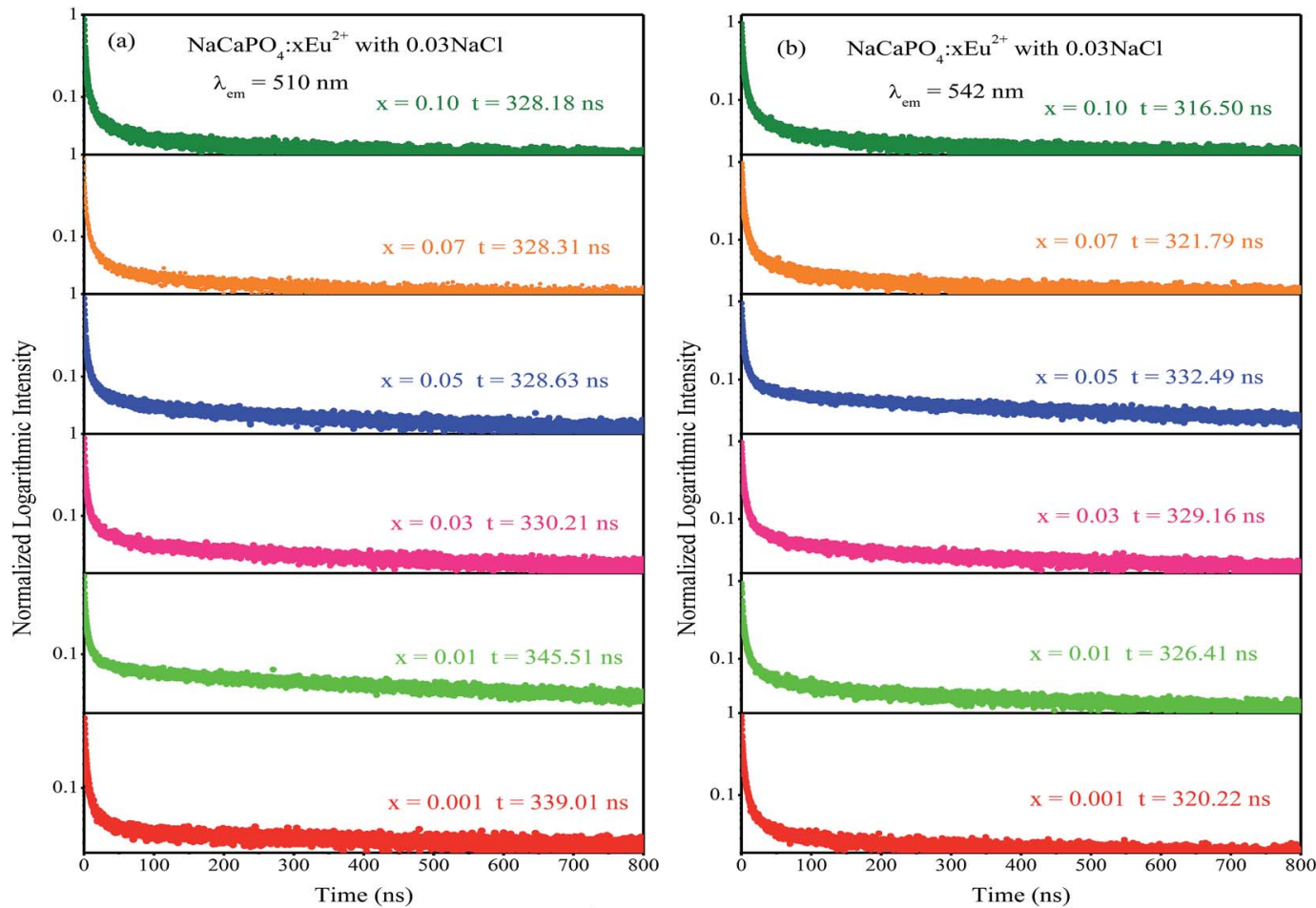

Fig. 10 Decay curves of $\mathrm{NaCaPO}_{4}: \mathrm{Eu}^{2+}$ with $0.03 \mathrm{NaCl}$ monitored at $510 \mathrm{~nm}(\mathrm{a})$ and $542 \mathrm{~nm}$ (b).
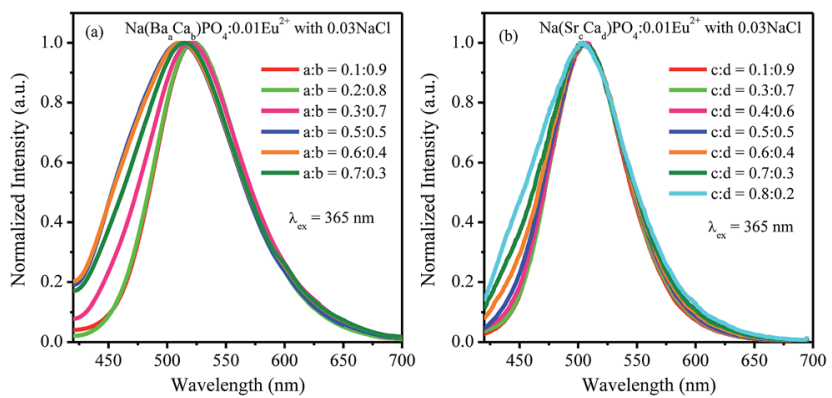

Fig. 11 Normalized emission spectra of $\mathrm{Na}\left(\mathrm{Ba}_{a} \mathrm{Ca}_{b}\right) \mathrm{PO}_{4}: 0.01 \mathrm{Eu}^{2+}$ and $\mathrm{Na}\left(\mathrm{Sr}_{c} \mathrm{Ca}_{d}\right) \mathrm{PO}_{4}: 0.01 \mathrm{Eu}^{2+}$ with $0.03 \mathrm{NaCl}$ excited at $365 \mathrm{~nm}$.

3.2.2.2 $\mathrm{Na}\left(\mathrm{Ba}_{a} \mathrm{Ca}_{b}\right) \mathrm{PO}_{4}: 0.01 \mathrm{Eu}^{2+}$ with $0.03 \mathrm{NaCl}$ and $\mathrm{Na}\left(\mathrm{Sr}_{c^{-}}\right.$ $\left.\mathrm{Ca}_{d}\right) \mathrm{PO}_{4}: 0.01 \mathrm{Eu}^{2+}$ with $0.03 \mathrm{NaCl} . \mathrm{Na}\left(\mathrm{Ba}_{a} \mathrm{Ca}_{b}\right) \mathrm{PO}_{4}: 0.01 \mathrm{Eu}^{2+}$ and $\mathrm{Na}\left(\mathrm{Sr}_{c} \mathrm{Ca}_{d}\right) \mathrm{PO}_{4}: 0.01 \mathrm{Eu}^{2+}$ with $0.03 \mathrm{NaCl}$ samples were synthesized using a fixed $\mathrm{Eu}^{2+}$ concentration of 0.01 . The normalized emission spectra of $\mathrm{Na}\left(\mathrm{Ba}_{a} \mathrm{Ca}_{b}\right) \mathrm{PO}_{4}: 0.01 \mathrm{Eu}^{2+}$ with $0.03 \mathrm{NaCl}$ and $\mathrm{Na}\left(\mathrm{Sr}_{c} \mathrm{Ca}_{d}\right) \mathrm{PO}_{4}: 0.01 \mathrm{Eu}^{2+}$ with $0.03 \mathrm{NaCl}$ are shown in Fig. 11a and $\mathrm{b}$, respectively, excited at $365 \mathrm{~nm}$. It can be seen that the emission spectra of $\mathrm{Na}\left(\mathrm{Ba}_{a} \mathrm{Ca}_{b}\right) \mathrm{PO}_{4}: 0.01 \mathrm{Eu}^{2+}$ with $0.03 \mathrm{NaCl}$ show an obvious blue shift with an increase in $\mathrm{Ba}^{2+}$ ions. However, when the ratio of $\mathrm{Ba}$ and $\mathrm{Ca}$ exceeded $0.5: 0.5$, the full width at half maximum decreased. For $\mathrm{Na}\left(\mathrm{Sr}_{c} \mathrm{Ca}_{d}\right) \mathrm{PO}_{4}: 0.01 \mathrm{Eu}^{2+}$ with $0.03 \mathrm{NaCl}$, the emission spectra show a broadened full width at half maximum with the increasing $\mathrm{Ba}^{2+}$ ions. Based on the abovementioned discussion, the emission spectra could be deconvoluted into two Gaussian components with the maxima at $510 \mathrm{~nm}(\mathrm{Eu}(2))$ and $542 \mathrm{~nm}(\mathrm{Eu}(1))$. For $\mathrm{Na}\left(\mathrm{Ba}_{a} \mathrm{Ca}_{b}\right)$
$\mathrm{PO}_{4}: 0.01 \mathrm{Eu}^{2+}$ with $0.03 \mathrm{NaCl}$ and $\mathrm{Na}\left(\mathrm{Sr}_{c} \mathrm{Ca}_{d}\right) \mathrm{PO}_{4}: 0.01 \mathrm{Eu}^{2+}$ with $0.03 \mathrm{NaCl}$, the fitted spectra of $510 \mathrm{~nm}$ and $542 \mathrm{~nm}$ are shown in Fig. 12a-d. The intensities of the $510 \mathrm{~nm}$ and $542 \mathrm{~nm}$ spectra for $\mathrm{Na}\left(\mathrm{Ba}_{a} \mathrm{Ca}_{b}\right) \mathrm{PO}_{4}: 0.01 \mathrm{Eu}^{2+}$ with $0.03 \mathrm{NaCl}$ increased with the increasing $\mathrm{Ba}^{2+}$ concentration up to $a: b=0.2: 0.8$. Due to the concentration quenching effect, the intensities decreased with further increase in the concentration of $\mathrm{Ba}^{2+}$ ions. $\mathrm{For} \mathrm{Na}\left(\mathrm{Sr}_{c^{-}}\right.$ $\left.\mathrm{Ca}_{d}\right) \mathrm{PO}_{4}: 0.01 \mathrm{Eu}^{2+}$ with $0.03 \mathrm{NaCl}$, the intensities of $510 \mathrm{~nm}$ and
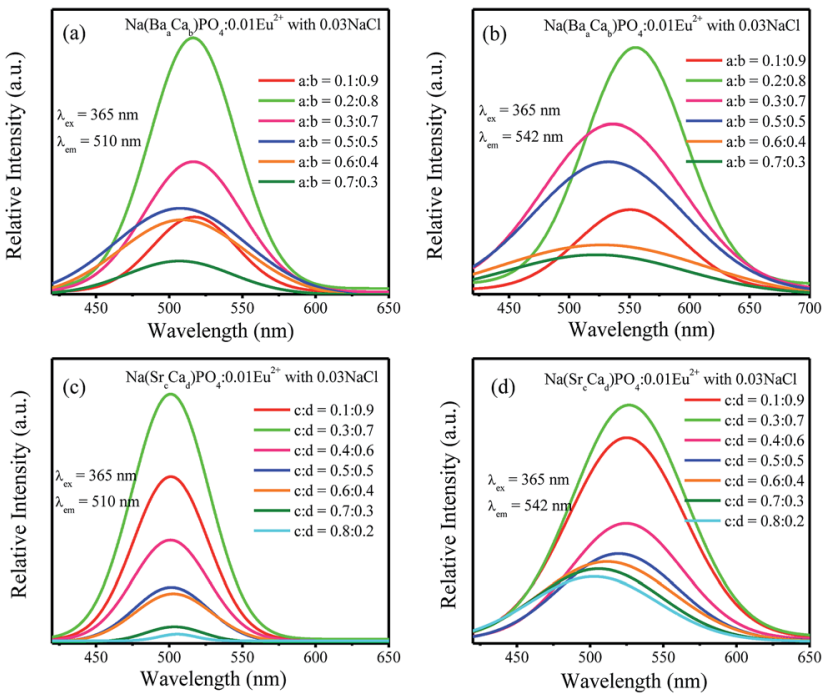

Fig. 12 (a)-(d) Fitted curves at $510 \mathrm{~nm}$ and $542 \mathrm{~nm}$ for $\mathrm{Na}\left(\mathrm{Ba}_{a} \mathrm{Ca}_{b}\right)$ $\mathrm{PO}_{4}: 0.01 \mathrm{Eu}^{2+}$ and $\mathrm{Na}\left(\mathrm{Sr}_{c} \mathrm{Ca}_{d}\right) \mathrm{PO}_{4}: 0.01 \mathrm{Eu}^{2+}$ with $0.03 \mathrm{NaCl}$ excited at $365 \mathrm{~nm}$. 

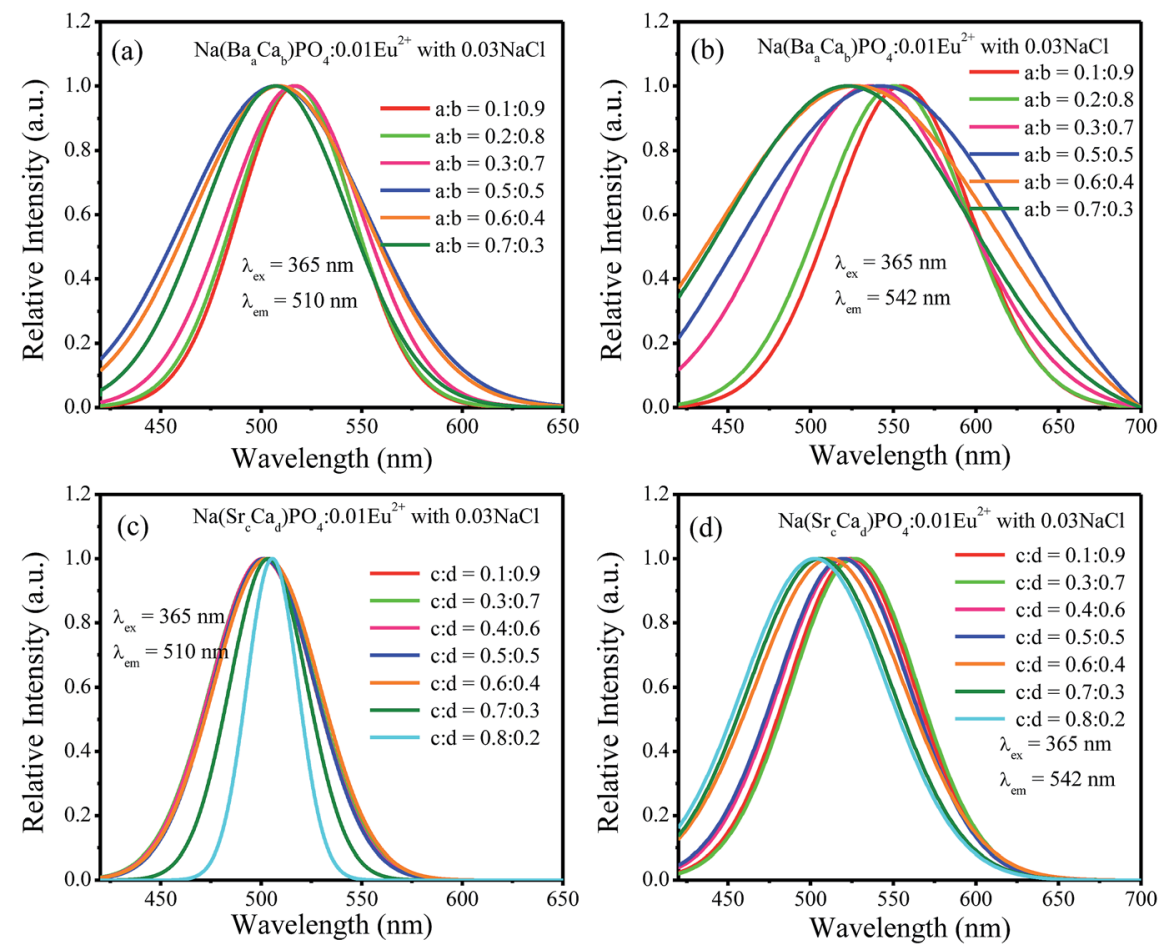

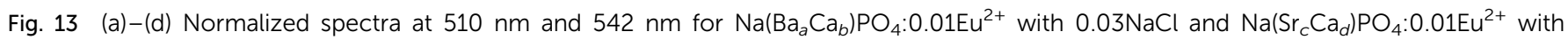
$0.03 \mathrm{NaCl}$ excited at $365 \mathrm{~nm}$.

$542 \mathrm{~nm}$ increased and reached maxima at $c: d=0.3: 0.7$ and then decreased with the increment of $\mathrm{Sr}^{2+}$ ions concentration. Fig. 13a-d show the normalized spectra of $510 \mathrm{~nm}$ and $542 \mathrm{~nm}$ for $\mathrm{Na}\left(\mathrm{Ba}_{a} \mathrm{Ca}_{b}\right) \mathrm{PO}_{4}: 0.01 \mathrm{Eu}^{2+}$ with $0.03 \mathrm{NaCl}$ and $\mathrm{Na}\left(\mathrm{Sr}_{c} \mathrm{Ca}_{d}\right)$ $\mathrm{PO}_{4}: 0.01 \mathrm{Eu}^{2+}$ with $0.03 \mathrm{NaCl}$ excited at $365 \mathrm{~nm}$. For $\mathrm{Na}\left(\mathrm{Ba}_{a} \mathrm{Ca}_{b}\right)$ $\mathrm{PO}_{4}: 0.01 \mathrm{Eu}^{2+}$ with $0.03 \mathrm{NaCl}$, it can be seen that the spectra of $510 \mathrm{~nm}$ and $542 \mathrm{~nm}$ shifted to a lower wavelength, as shown in Fig. 13a and b, respectively. Moreover, the full width at half maximum of the $510 \mathrm{~nm}$ spectra for $\mathrm{Na}\left(\mathrm{Ba}_{a} \mathrm{Ca}_{b}\right) \mathrm{PO}_{4}: 0.01 \mathrm{Eu}^{2+}$ with $0.03 \mathrm{NaCl}$ decreased when the ratio of $\mathrm{Ba}$ to $\mathrm{Ca}$ exceeded 0.5 : 0.5. However, for $\mathrm{Na}\left(\mathrm{Sr}_{c} \mathrm{Ca}_{d}\right) \mathrm{PO}_{4}: 0.01 \mathrm{Eu}^{2+}$ with $0.03 \mathrm{NaCl}$, the full width at half maximum of $510 \mathrm{~nm}$ spectra decreased when the radio of $\mathrm{Sr}$ and $\mathrm{Ca}$ was greater than $0.7: 0.3$, and no shift could be observed. The $542 \mathrm{~nm}$ spectra showed a blue shift

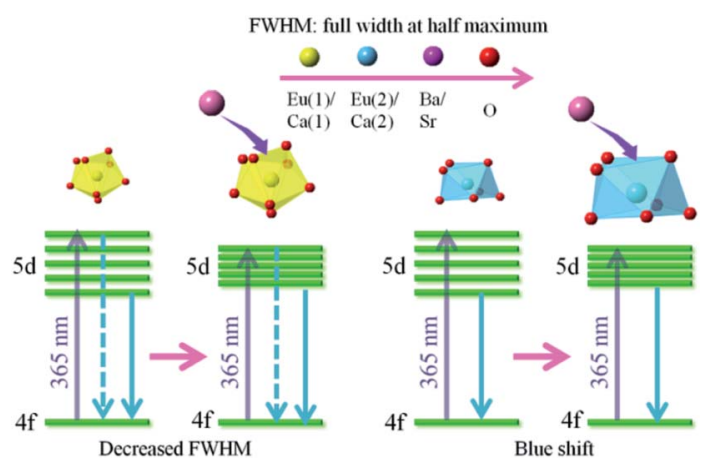

Fig. 14 Schematic of the mechanism accounting for the decreased full width at half maximum and blue shift of $\mathrm{Eu}^{2+}$ emission. with the increase of $\mathrm{Sr}^{2+}$ ions. Generally, the crystal field splitting $\left(D_{\mathrm{q}}\right)$ trends with bond length can be determined by the following equation: ${ }^{38-40}$

$$
D_{\mathrm{q}}=Z e^{2} r^{4} / 6 R^{5}
$$

where $D_{\mathrm{q}}$ is the magnitude of the $5 \mathrm{~d}$ energy level separation, $Z$ represents the anion charge or valence, $e$ is the electron charge, $r$ is the radius of the $d$ wave function, and $R$ is the bond length. The bond length of $\mathrm{Ce}-\mathrm{O}$ will increase due to the lattice expansion because the radii of $\mathrm{Ba}^{2+}$ and $\mathrm{Sr}^{2+}$ are larger than that of $\mathrm{Ca}^{2+}$. Hence, the crystal field splitting will become weaker, which causes a blue shift and decreases full width at half maximum. The schematic mechanism of the decreased full width at half maximum and blue shift of $\mathrm{Eu}^{2+}$ emission is shown in Fig. 14 when $\mathrm{Ba}^{2+}$ and $\mathrm{Sr}^{2+}$ were substituted for $\mathrm{Ca}^{2+}$ in $\mathrm{NaCaPO}_{4}: 0.01 \mathrm{Eu}^{2+}$ with $0.03 \mathrm{NaCl}$. The blue shift of $\mathrm{Na}\left(\mathrm{Ba}_{a} \mathrm{Ca}_{b}\right)$ $\mathrm{PO}_{4}: 0.01 \mathrm{Eu}^{2+}$ with $0.03 \mathrm{NaCl}$ was greater than that of $\mathrm{Na}\left(\mathrm{Sr}_{c} \mathrm{Ca}_{d}\right)$ $\mathrm{PO}_{4}: 0.01 \mathrm{Eu}^{2+}$ with $0.03 \mathrm{NaCl}$, which is due to that fact that the radius of $\mathrm{Ba}^{2+}\left(r_{\mathrm{Ba}}=1.34 \mathrm{~nm}\right)$ is larger than that of $\mathrm{Sr}^{2+}\left(r_{\mathrm{Sr}}=\right.$ $1.12 \mathrm{~nm})$. The crystal field splitting of $\mathrm{Na}\left(\mathrm{Ba}_{a} \mathrm{Ca}_{b}\right) \mathrm{PO}_{4}: 0.01 \mathrm{Eu}^{2+}$ with $0.03 \mathrm{NaCl}$ was weaker, and a more obvious blue shift could be observed. For $\mathrm{Na}\left(\mathrm{Sr}_{c} \mathrm{Ca}_{d}\right) \mathrm{PO}_{4}: 0.01 \mathrm{Eu}^{2+}$ with $0.03 \mathrm{NaCl}$, comparing the decreased full width at half maximum of the $510 \mathrm{~nm}$ band and the blue shift of the $542 \mathrm{~nm}$ band, the difference may be that $\mathrm{Eu}^{2+}$ had different coordinations (i.e., eight and seven coordination). Therefore, the emission properties could be tuned by controlling the concentration of $\mathrm{Ba}^{2+}$ or $\mathrm{Sr}^{2+}$. Fig. 15a and b show CIE chromaticity coordinates and images of $\mathrm{Na}\left(\mathrm{Ba}_{a} \mathrm{Ca}_{b}\right) \mathrm{PO}_{4}: 0.01 \mathrm{Eu}^{2+}$ with $0.03 \mathrm{NaCl}$ and 

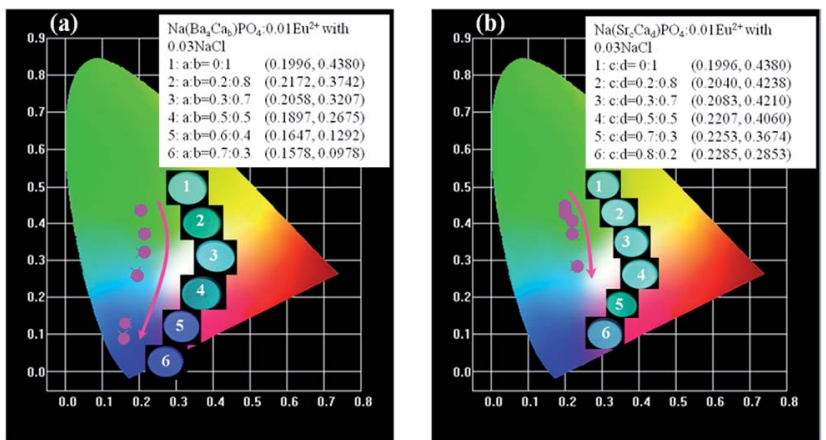

Fig. $15 \mathrm{ClE}$ chromaticity coordinates and images of $\mathrm{Na}\left(\mathrm{Ba}_{a} \mathrm{Ca}_{b}\right)$ $\mathrm{PO}_{4}: 0.01 \mathrm{Eu}^{2+}$ with $0.03 \mathrm{NaCl}$ (a) and $\mathrm{Na}\left(\mathrm{Sr}_{c} \mathrm{Ca}_{d}\right) \mathrm{PO}_{4}: 0.01 \mathrm{Eu}^{2+}$ with $0.03 \mathrm{NaCl}(\mathrm{b})$ under a $365 \mathrm{~nm}$ UV lamp.

$\mathrm{Na}\left(\mathrm{Sr}_{c} \mathrm{Ca}_{d}\right) \mathrm{PO}_{4}: 0.01 \mathrm{Eu}^{2+}$ with $0.03 \mathrm{NaCl}$ under a $365 \mathrm{~nm} \mathrm{UV}$ lamp. It can be seen that the emission color of $\mathrm{Na}\left(\mathrm{Ba}_{a} \mathrm{Ca}_{b}\right)$ $\mathrm{PO}_{4}: 0.01 \mathrm{Eu}^{2+}$ with $0.03 \mathrm{NaCl}$ and $\mathrm{Na}\left(\mathrm{Sr}_{c} \mathrm{Ca}_{d}\right) \mathrm{PO}_{4}: 0.01 \mathrm{Eu}^{2+}$ with $0.03 \mathrm{NaCl}$ could change from green $(0.1996,0.4380)$ to blue $(0.1578,0.0978)$ or to cyan $(0.2285,0.2853)$, respectively. The corresponding images of the samples are shown in Fig. 15.

For LED applications, the thermal stability of the phosphor is one of the important parameters. The temperaturedependent emission spectra of $\mathrm{Na}\left(\mathrm{Ba}_{0.7} \mathrm{Ca}_{0.3}\right) \mathrm{PO}_{4}: 0.01 \mathrm{Eu}^{2+}$ with $0.03 \mathrm{NaCl}$ and $\mathrm{Na}\left(\mathrm{Sr}_{0.8} \mathrm{Ca}_{0.2}\right) \mathrm{PO}_{4}: 0.01 \mathrm{Eu}^{2+}$ with $0.03 \mathrm{NaCl}$ under the excitation of $365 \mathrm{~nm}$ were investigated, as shown in Fig. 16a and b, respectively. It was observed that the emission intensity continuously decreased with the increasing temperature from room temperature to $200{ }^{\circ} \mathrm{C}$. The emission intensity of $\mathrm{Na}\left(\mathrm{Ba}_{0.7} \mathrm{Ca}_{0.3}\right) \mathrm{PO}_{4}: 0.01 \mathrm{Eu}^{2+}$ with $0.03 \mathrm{NaCl}$ and $\mathrm{Na}\left(\mathrm{Sr}_{0.8} \mathrm{Ca}_{0.2}\right)$ $\mathrm{PO}_{4}: 0.01 \mathrm{Eu}^{2+}$ with $0.03 \mathrm{NaCl}$ decreased to $90 \%$ and $76 \%$ of the initial emission intensity, respectively, corresponding to $100{ }^{\circ} \mathrm{C}$. It can be seen that the thermal quenching of $\mathrm{Na}\left(\mathrm{Sr}_{0.8} \mathrm{Ca}_{0.2}\right)$
$\mathrm{PO}_{4}: 0.01 \mathrm{Eu}^{2+}$ with $0.03 \mathrm{NaCl}$ was inferior to that of $\mathrm{Na}\left(\mathrm{Ba}_{0.7^{-}}\right.$ $\left.\mathrm{Ca}_{0.3}\right) \mathrm{PO}_{4}: 0.01 \mathrm{Eu}^{2+}$ with $0.03 \mathrm{NaCl}$. The reason is that in $\mathrm{Na}(\mathrm{Ba} /$ $\mathrm{Sr} / \mathrm{Ca}) \mathrm{PO}_{4}: \mathrm{Eu}^{2+}$ with $\mathrm{NaCl}$, with the replacement of $\mathrm{Eu}^{2+}-\mathrm{Eu}^{2+}$ neighbors by $\mathrm{Eu}^{2+}-\mathrm{Ba}^{2+} / \mathrm{Sr}^{2+}$ pairs, the emission intensity will decrease with an increment in temperature due to the lower nonradiative decay rate from the lowest excited state, according to Peng et al. ${ }^{41}$ The bond length will become shorter when $\mathrm{Ba}^{2+}$ is co-doped in $\mathrm{NaCaPO}_{4}: \mathrm{Eu}^{2+}$ with $\mathrm{NaCl}$ with respect to $\mathrm{Sr}^{2+}$ codoping because the radius of $\mathrm{Ba}^{2+}$ is larger than that of $\mathrm{Sr}^{2+}$. The thermal excitation from $\mathrm{Eu}^{2+}-\mathrm{Ba}^{2+} / \mathrm{Sr}^{2+}$ may occur differently with an increase in temperature. Hence, co-doping Sr will lead to worse thermal quenching compared to co-doping Ba due to covalent effects. The slightly decreased intensity indicated that the $\mathrm{Na}(\mathrm{Ba} / \mathrm{Sr} / \mathrm{Ca}) \mathrm{PO}_{4}: 0.01 \mathrm{Eu}^{2+}$ with $0.03 \mathrm{NaCl}$ phosphor could be applied to a white LED. To investigate the relationship of luminescence with temperature and to calculate the activation energy from thermal quenching, the activation energy $\left(E_{\mathrm{a}}\right)$ can be expressed by the following formula: ${ }^{42}$

$$
I=I_{0} /\left[1+c \exp \left(-E_{\mathrm{a}} / k T\right)\right]
$$

where $I$ and $I_{0}$ are the luminescence intensities of the phosphor at the testing temperature and room temperature, respectively, $E_{\mathrm{a}}$ represents the thermal quenching activation energy of the phosphor, $c$ is the rate constant for thermally activated escape, and $k$ is the Boltzmann constant $\left(8.629 \times 10^{-5} \mathrm{eV} \mathrm{K}^{-1}\right)$. The inset of Fig. 16a and b show the plots of $\ln \left[\left(I_{0} / I\right)-1\right]$ versus $1 / T$ for $\mathrm{Na}\left(\mathrm{Ba}_{0.7} \mathrm{Ca}_{0.3}\right) \mathrm{PO}_{4}: 0.01 \mathrm{Eu}^{2+}$ with $0.03 \mathrm{NaCl}$ and $\mathrm{Na}\left(\mathrm{Sr}_{0.8} \mathrm{Ca}_{0.2}\right)$ $\mathrm{PO}_{4}: 0.01 \mathrm{Eu}^{2+}$ with $0.03 \mathrm{NaCl}$, respectively. The calculated $E_{\mathrm{a}}$ were 0.1506 and $0.2399 \mathrm{eV}$ for $\mathrm{Na}\left(\mathrm{Ba}_{0.7} \mathrm{Ca}_{0.3}\right) \mathrm{PO}_{4}: 0.01 \mathrm{Eu}^{2+}$ with $0.03 \mathrm{NaCl}$ and $\mathrm{Na}\left(\mathrm{Sr}_{0.8} \mathrm{Ca}_{0.2}\right) \mathrm{PO}_{4}: 0.01 \mathrm{Eu}^{2+}$ with $0.03 \mathrm{NaCl}$, which indicate that the phosphors show relatively good thermal stability and can be used in an LED.

To verify the actual application of the phosphor, we chose the sample with the broadest full width at half maximum to fabricate
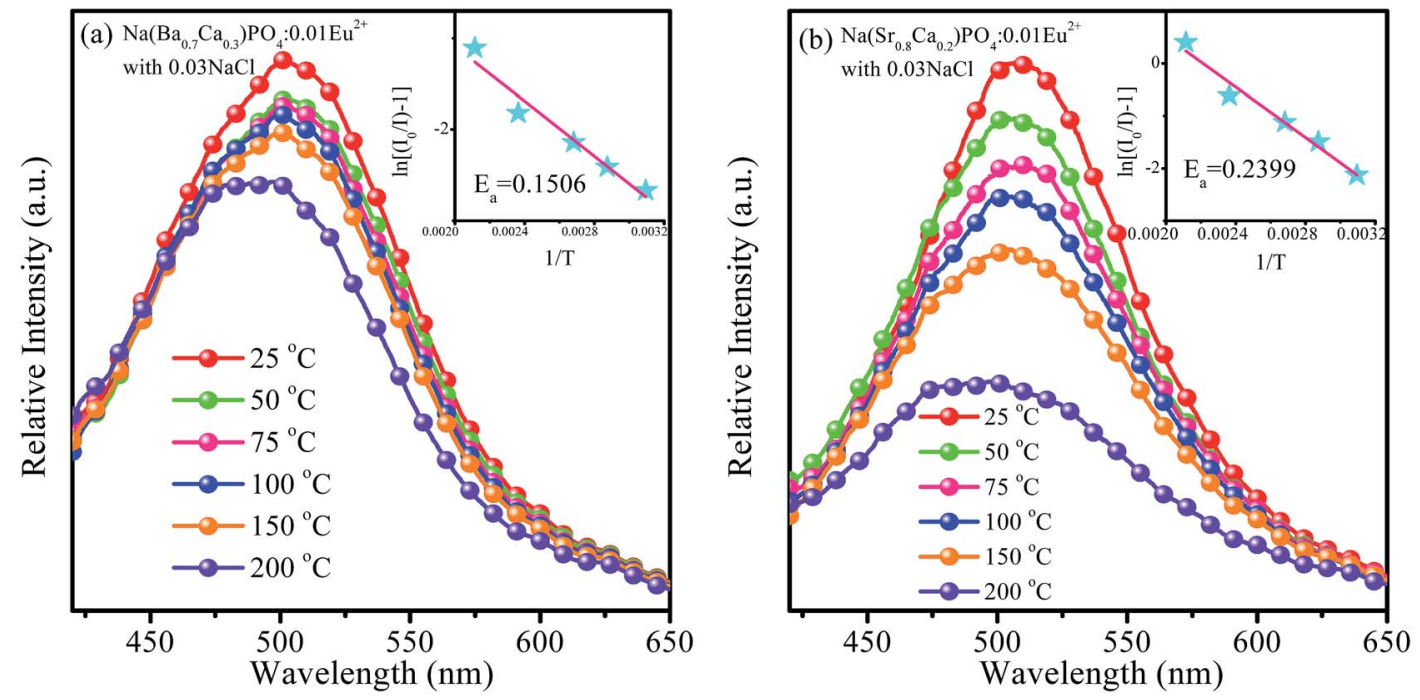

Fig. 16 Temperature-dependent emission spectra of $\mathrm{Na}\left(\mathrm{Ba}_{0.7} \mathrm{Ca}_{0.3}\right) \mathrm{PO}_{4}: 0.01 \mathrm{Eu}^{2+}$ with $0.03 \mathrm{NaCl}$ (a) and $\mathrm{Na}\left(\mathrm{Sr}_{0.8} \mathrm{Ca}_{0.2}\right) \mathrm{PO}_{4}: 0.01 \mathrm{Eu}^{2+}$ with $0.03 \mathrm{NaCl}$ (b) excited at $365 \mathrm{~nm}$. The inset shows the activation energy of $\mathrm{Na}\left(\mathrm{Ba}_{0.7} \mathrm{Ca}_{0.3}\right) \mathrm{PO}_{4}: 0.01 \mathrm{Eu}^{2+}$ with $0.03 \mathrm{NaCl}(\mathrm{a})$ and $\mathrm{Na}\left(\mathrm{Sr}_{0.8} \mathrm{Ca} \mathrm{a}_{0.2}\right)$ $\mathrm{PO}_{4}: 0.01 \mathrm{Eu}^{2+}$ with $0.03 \mathrm{NaCl}(\mathrm{b})$. 


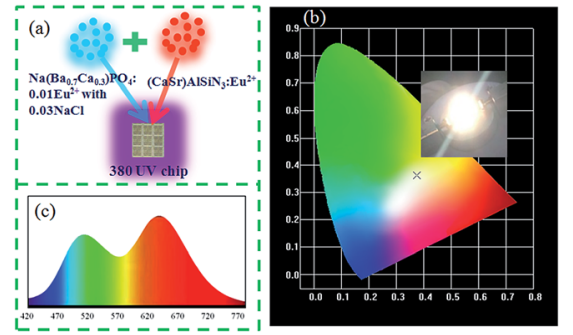

Fig. 17 (a) Diagram of white LED package. (b) CIE chromaticity coordinates and photos of white LED, which is fabricated by $\mathrm{Na}\left(\mathrm{Ba}_{0.7} \mathrm{Ca}_{0.3}\right) \mathrm{PO}_{4}: 0.01 \mathrm{Eu}^{2+}$ with $0.03 \mathrm{NaCl}$ and (CaSr)AISiN $3: \mathrm{Eu}^{2+}$ phosphors. (c) Electroluminescence spectra of white LED composed of a $380 \mathrm{~nm}$ UV chip.

a white LED. The devices were combined with a $380 \mathrm{~nm}$ UV chip $(\mathrm{CaSr}) \mathrm{AlSiN}_{3}: \mathrm{Eu}^{2+}$ and $\mathrm{Na}\left(\mathrm{Ba}_{0.7} \mathrm{Ca}_{0.3}\right) \mathrm{PO}_{4}: 0.01 \mathrm{Eu}^{2+}$ with $0.03 \mathrm{NaCl}$ phosphors, Fig. 17a. CIE coordinates were $(0.3750,0.3634)$, and the image shows an excellent white light, as shown in Fig. 17b. Fig. 17c shows the electroluminescence spectrum of the white LED. Tt can be seen that the spectrum shows a stronger emission in the range of $480-510 \mathrm{~nm}$. The quantum efficiency of $\mathrm{Na}\left(\mathrm{Ba}_{0.7} \mathrm{Ca}_{0.3}\right) \mathrm{PO}_{4}: 0.01 \mathrm{Eu}^{2+}$ with $0.03 \mathrm{NaCl}$ was $45.06 \%$. Therefore, $\mathrm{Na}(\mathrm{Ba} / \mathrm{Sr} / \mathrm{Ca}) \mathrm{PO}_{4}: 0.01 \mathrm{Eu}^{2+}$ with $0.03 \mathrm{NaCl}$ has potential applications in white LEDs.

\section{Conclusions}

In summary, a series of $\mathrm{Na}(\mathrm{Ba} / \mathrm{Sr} / \mathrm{Ca}) \mathrm{PO}_{4}: 0.01 \mathrm{Eu}^{2+}$ with $0.03 \mathrm{NaCl}$ phosphors were synthesized via a high-temperature solid-state reaction method. On the one hand, the luminescence intensity of $\mathrm{NaCaPO}_{4}: \mathrm{Eu}^{2+}$ was enhanced using $\mathrm{NaCl}$ as the aid-sintering additives, and the phases were indexed to pure $\mathrm{NaCaPO}_{4}$. $\mathrm{NaCaPO}_{4}: \mathrm{Eu}^{2+}$ exhibited the strongest emission when the concentration of $\mathrm{NaCl}$ was $0.03 . \mathrm{NaCaPO}_{4}: \mathrm{Eu}^{2+}$ with $0.03 \mathrm{NaCl}$ exhibited two green emission bands at 510 and $542 \mathrm{~nm}$, which were ascribed to two different Ca sites with different coordination (i.e., eight and seven coordination). On the other hand, by gradually introducing $\mathrm{Ba}^{2+}$ or $\mathrm{Sr}^{2+}$ into $\mathrm{NaCaPO}_{4}: 0.01 \mathrm{Eu}^{2+}$ with $0.03 \mathrm{NaCl}, 510$ and $542 \mathrm{~nm}$ emission bands showed various full width at half maximum and a blue shift caused by the crystal field splitting. The intensity of cyan region from 480 to $510 \mathrm{~nm}$ increased by controlling the $\mathrm{Ba}$ or $\mathrm{Sr}$ concentration. Compared to a $\mathrm{Sr}^{2+}$-doped phosphor, $\mathrm{Na}(\mathrm{BaCa}) \mathrm{PO}_{4}: 0.01 \mathrm{Eu}^{2+}$ with $0.03 \mathrm{NaCl}$ exhibited a more obvious blue shift because the radius of $\mathrm{Ba}^{2+}$ is larger than that of $\mathrm{Sr}^{2+}$. Therefore, luminescence of $\mathrm{Na}(\mathrm{Ba} / \mathrm{Sr} / \mathrm{Ca})$ $\mathrm{PO}_{4}: 0.01 \mathrm{Eu}^{2+}$ with $0.03 \mathrm{NaCl}$ could be tuned from green $(0.1996$, $0.4380)$ to blue $(0.1578,0.0978)$ under the same excitation by introducing $\mathrm{Sr}^{2+}$ or $\mathrm{Ba}^{2+}$ ions. Moreover, these phosphors can be used in UV/n-UV-pumped white LEDs.

\section{Acknowledgements}

The work was supported by the National Natural Science Foundation of China (No. 51672066), the Funds for Distinguished Young Scientists of Hebei Province, China (No.
A2015201129), the personnel training project of Hebei Province, China (No. A2016002013), and the Post-graduate's Innovation Fund Project of Hebei University (No. X2016063, X2016064).

\section{References}

1 H. Ji, L. Wang, M. S. Molokeev, N. Hirosaki, R. Xie, Z. Huang, Z. Xia, O. M. Kate, L. Liu and V. V. Atuchin, J. Mater. Chem. C, 2016, 4, 6855-6863.

2 F. Kang, H. Zhang, L. Wondraczek, X. Yang, Y. Zhang, D. Y. Lei and M. Peng, Chem. Mater., 2016, 28, 2692-2703.

3 S.-P. Lee, S.-D. Liu, T.-S. Chan and T.-M. Chen, ACS Appl. Mater. Interfaces, 2016, 8, 9218-9223.

4 X. Y. Liu, H. Guo, Y. Liu, S. Ye, M. Y. Peng and Q. Y. Zhang, J. Mater. Chem. C, 2016, 4, 2506-2512.

5 H. C. Yoon, H. Kang, S. Lee, J. H. Oh, H. Yang and Y. R. Do, ACS Appl. Mater. Interfaces, 2016, 8, 18189-18200.

6 L. Wang, B. K. Moon, S. H. Park, J. H. Kim, J. Shi, K. H. Kim and J. H. Jeong, RSC Adv., 2016, 6, 79317-79324.

7 F. Pan, M. Zhou, J. Zhang, X. Zhang, J. Wang, L. Huang, X. Kuang and M. Wu, J. Mater. Chem. C, 2016, 4, 5671-5678.

8 A. A. Setlur, W. J. Heward, Y. Gao, A. M. Srivastava, R. G. Chandran and M. V. Shankar, Chem. Mater., 2006, 18, 3314-3322.

9 X. Piao, T. Horikawa, H. Hanzawa and K. I. Machida, Appl. Phys. Lett., 2006, 88, 161908.

10 X. Gong, J. Huang, Y. Chen, Y. Lin, Z. Luo and Y. Huang, Inorg. Chem., 2014, 53, 6607-6614.

11 K. Li, Y. Zhang, X. Li, M. Shang, H. Lian and J. Lin, Phys. Chem. Chem. Phys., 2015, 17, 4283-4292.

12 H. S. Jang, W. B. Im, D. C. Lee, D. Y. Jeon and S. S. Kim, J. Lumin., 2007, 126, 371-377.

13 Y. Zhang, X. Li, K. Li, H. Lian, M. Shang and J. Lin, ACS Appl. Mater. Interfaces, 2015, 7, 2715-2725.

14 D. Wen, J. Feng, J. Li, J. Shi, M. Wu and Q. Su, J. Mater. Chem. C, 2015, 3, 2107-2114.

15 L. Jiang, R. Pang, D. Li, W. Sun, Y. Jia, H. Li, J. Fu, C. Li and S. Zhang, Dalton Trans., 2015, 44, 17241-17250.

16 C. C. Lin, Z. R. Xiao, G.-Y. Guo, T.-S. Chan and R.-S. Liu, J. Am. Chem. Soc., 2010, 132, 3020-3028.

17 M.-H. Fang, C. Ni, X. Zhang, Y.-T. Tsai, S. Mahlik, A. Lazarowska, M. Grinberg, H.-S. Sheu, J.-F. Lee, B.-M. Cheng and R.-S. Liu, ACS Appl. Mater. Interfaces, 2016, 8, 30677-30682.

18 F. Kang, M. Peng, D. Y. Lei and Q. Zhang, Chem. Mater., 2016, 28, 7807-7815.

19 W. L. Wanmaker and H. L. Spier, J. Electrochem. Soc., 1962, 109, 109-114.

20 M. S. Waite, J. Electrochem. Soc., 1974, 121, 1122-1123.

21 W. L. Wanmaker, A. Bril and J. W. ter Vrugt, Appl. Phys. Lett., 1966, 8, 260-261.

22 C. S. Liang, H. Eckert, T. E. Gier and G. D. Stucky, Chem. Mater., 1993, 5, 597-603.

23 Z. C. Wu, J. X. Shi, M. L. Gong, J. Wang and Q. Su, Mater. Chem. Phys., 2007, 103, 415-418.

24 Z. C. Wu, J. X. Shi, J. Wang, M. L. Gong and Q. Su, J. Solid State Chem., 2006, 179, 2356-2360. 
25 Y. S. Tang, S. F. Hu, C. C. Lin, N. C. BagKar and R. S. Liu, Appl. Phys. Lett., 2007, 90, 151108.

26 Z. P. Yang, G. W. Yang, S. L. Wang, J. Tian, X. N. Li, Q. L. Guo and G. S. Fu, Mater. Lett., 2008, 62, 1884-1886.

27 Y. Wang, M. G. Brik, P. Dorenbos, Y. Huang, Y. Tao and H. Liang, J. Phys. Chem. C, 2014, 118, 7002-7009.

28 C. Larson and R. B. Von Dreele, Los Alamos National Laboratory Report LAUR, Los Alamos National Laboratory, Los Alamos, 2000, vol. 86, pp. 748-789.

29 W. Tang and Z. Zhang, J. Mater. Chem. C, 2015, 3, 5339-5346.

30 X. J. Wang, L. Wang, T. Takeda, S. Funahashi, T. Suehiro, N. Hirosaki and R. Xie, Chem. Mater., 2015, 27, 7689-7697. 31 L. G. Van Uitert, J. Lumin., 1984, 29, 1-9.

32 L. Ozawa and P. M. Jaffe, J. Electrochem. Soc., 1971, 118, 1678-1679.

33 L. G. Van Uitert, J. Electrochem. Soc., 1967, 114, 1048-1053.

34 C. Huang, Y. Chiu, Y. Yeh, T. Chan and T. Chen, ACS Appl. Mater. Interfaces, 2012, 4, 6661-6668.
35 B. Wang, H. Lin, J. Xu, H. Chen and Y. Wang, ACS Appl. Mater. Interfaces, 2014, 6, 22905-22913.

36 Y. Jia, H. Qiao, Y. Zheng, N. Guo and H. You, Phys. Chem. Chem. Phys., 2012, 14, 3537-3542.

37 Y. Shimomura, T. Honma, M. Shigeiwa, T. Akai, K. Okamoto and N. Kijima, J. Electrochem. Soc., 2007, 154, J35-J38.

38 C. K. Jorgensen, Modern Aspects of Ligand-Field Theory, Amsterdam, North-Holland, 1971.

39 M. Shang, J. Fan, H. Lian, Y. Zhang, D. Geng and J. Lin, Inorg. Chem., 2014, 53, 7748-7755.

40 Y. Xia, J. Chen, Y. Liu, M. S. Molokeev, M. Guan, Z. Huang and M. Fang, Dalton Trans., 2016, 45, 1007-1015.

41 M. Peng, X. Yin, P. A. Tanner, M. G. Brik and P. Li, Chem. Mater., 2015, 27, 2938-2945.

42 S. Bhushan and M. V. Chukichev, J. Mater. Sci. Lett., 1988, 74, 319-321. 